\title{
Retórica como metódica para estudo do direito
}

\author{
João Maurício Adeodato*
}

\begin{abstract}
Sumário: Introdução: retórica e perspectiva do mundo; 1. Os fundamentos: ethos, pathos e $\operatorname{logos}$; 2. Da sofística à retórica: inserções de historicismo, ceticismo e humanismo; 3 . Três dimensões da retórica: retórica como método, metodologia e metódica; 4. Desenvolvimentos futuros para uma retórica metódica desestruturante.
\end{abstract}

\begin{abstract}
Resumo: Para as filosofias ontológicas, essencialistas, claramente dominantes na tradição ocidental e na filosofia do direito atual, a linguagem é mero instrumento, um meio para a descoberta da verdade, que pode ser aparente, para umas, ou se esconder por trás das aparências, para outras, com todas as combinações e ecletismos. O comum é a idéia de que, com método, lógica, intuição, emoção e todo seu aparato cognoscitivo competentemente aplicado, é possível aos seres humanos chegar à verdade, assertiva que coagiria todos a aceitá-la ("racionalidade"). No campo ético, a verdade equivale a correto, justo e outros adjetivos laudatórios. Este artigo defende a tese de que isso é uma ilusão altamente funcional e que os precários acordos da linguagem não são apenas o máximo de garantia possível, são a única. E ainda que seja temporária, autopoiética, circunstancial e freqüentemente rompida em suas promessas, é só o que se pode chamar de "racionalidade".

Palavras-chave: Retórica metódica; Metodologia e Método retórico; Historicismo, Ceticismo; Humanismo.
\end{abstract}

Abstract: According to ontological, essentialist philosophies, clearly prevailing in Western tradition and in contemporary philosophy of law, language is a mere instrument to the discovery of truth, which can be apparent to some, or to hide behind appearances, to others, with all combinations and eclecticisms. The common idea is that with method, logic, intuition, emotion and all their knowledge apparatus, it is possible for human beings to find truth, statements which would compel everyone to acceptance ("rationality"). In what ethics is concerned, truth equals correctness, justice and other laudatory adjectives. This paper defends the thesis that this is a highly functional illusion and that the precarious agreements of language not only constitute the maximum possible guarantees, they are the only ones. Moreover, despite being temporary, autopoietic, circumstantial and frequently disrespected, this is all that can be called rationality.

Keywords: Rethorical methodic. Methodology and rethorical method. Historicism. Skepticism. Humanism.

\section{Introdução: retórica e perspectiva do mundo}

Este texto tem por objetivo expor o entendimento de que a retórica é uma maneira de "experimentar" o mundo, com as associações que o verbo acarreta, a exemplo de "olhar", "sentir", "pensar", "provar", “julgar". É uma maneira de ao mesmo

\footnotetext{
* Professor Titular da Faculdade de Direito do Recife, Pesquisador 1-A do CNPq.
} 
tempo observar e estar no ambiente. Isso significa dizer que a retórica não é exatamente uma filosofia, nem tampouco uma escola de pensamento.

Dependendo da amplitude que se tenha do conceito de filosofia, a retórica pode estar dentro ou fora dela. Se a filosofia é a busca pela verdade, a retórica prescinde desse conceito e, assim, não está dentro da filosofia. Ottmar Ballweg separa retórica e filosofia segundo esse critério e exclui desta última correntes de pensamento como ceticismo, agnosticismo, voluntarismo, nominalismo, positivismo, pragmatismo e niilismo ${ }^{1}$.

Mas, se a concepção que se tem de filosofia não tem a verdade como pressuposto de investigação, aí a postura retórica se opõe à ontológica, ambas constituindo uma das dicotomias básicas da filosofia ocidental. Este artigo parte da concepção da retórica como uma espécie de filosofia, mais do que uma "escola", dadas suas amplitude, longevidade e abrangência.

Esse tipo de filosofia se caracteriza por achar que a linguagem (retórica) é o ponto comum dessas "realidades em que vivemos" (Blumenberg) e, como tal, o único campo para o conhecimento bem peculiar que o ser humano pode ter do mundo (o conhecimento retórico). São retóricas todas as concepções filosóficas que partem de uma antropologia "pobre", enquanto são ontológicas todas aquelas que tomam por base uma antropologia "rica". Transcreva-se um pequeno resumo do que foi estudado com mais detalhes anteriormente e que agora se toma como pressuposto já discutido:

"Na linha de Arnold Gehlen, Hans Blumenberg resume em duas tendências opostas as bases antropológicas de uma evolução na concepção da teoria do conhecimento que pode ser detectada no Ocidente, divisão que se pode fazer aqui corresponder à dicotomia essencialismo versus retórica, ou à dicotomia verdade versus conjetura. Uma das mudanças de paradigma na perspectiva da modernidade e da pós-modernidade seria exatamente deixar de ver o ser humano como espécie triunfante que domina a natureza, constrói seu próprio mundo e representa a 'coroa da criação', como queriam a filosofia da história e a biologia evolucionária, para entendê-lo como ser retardado, metafórico, intermediado em sua relação com o meio ambiente, dominado pela necessidade de compensação em virtude de seu distanciamento da natureza circundante. Na terminologia de Gehlen, o ser humano ora é visto pela antropologia filosófica como um ente rico ou pleno (reiches Wesen), ora como um ente pobre ou carente (armes Wesen), segundo suas relações com o meio circundante". ${ }^{2}$

${ }^{1}$ BALLWEG, Ottmar. Phronetik, Semiotik und Rhetorik, in: BALLWEG, Ottmar; SEIBERT, ThomasMichael (Hrsg.). Rhetorische Rechtstheorie. Freiburg-München: Alber, 1982, p. 27-71.

${ }^{2}$ ADEODATO, João Maurício. Conjetura e verdade, in: ADEODATO, João Maurício. Ética e retórica - para uma teoria da dogmática jurídica, 3. ed. rev. e ampl. São Paulo: Saraiva, 2007, p. 309 s. 
Para as filosofias ontológicas, essencialistas, a linguagem é mero instrumento, um meio para a descoberta da verdade, que pode ser aparente, para uns, ou se esconder por trás das aparências, para outros, com todas as combinações e ecletismos. O importante é a idéia de que, com método, lógica, intuição, emoção e todo seu aparato cognoscitivo competentemente aplicado, é possível aos seres humanos chegar à verdade, a uma conclusão que coagiria todos a aceitá-la. No campo ético, a verdade equivale ao correto, ao justo. Para os retóricos dos mais diversos matizes, contrariamente, o ponto comum é a convicção de que isso é uma ilusão e a linguagem não é apenas o máximo de acordo possível, é o único. E ainda que esse acordo seja temporário, circunstancial e muitas vezes rompido, é só o que se pode chamar de "racionalidade".

"Enquanto pleno, o ser humano possui o critério e é capaz de chegar à verdade, servindo-lhe a língua apenas como instrumento e a retórica como simples ornamento, pelos quais aquele que fala pode influir no meio de forma mais ou menos eficaz; como ser deficiente ou carente, o ser humano é incapaz de perceber quaisquer verdades a respeito do mundo, independentemente de um contexto lingüístico, única realidade artificial com que é capaz de lidar.

Assim é colocado o problema: a linguagem e tudo o que se convencionou chamar de 'inteligência', 'mente', 'espírito', pode ser visto como um plus, como habitualmente é feito na cultura ocidental, mas também como um minus. E o que se denomina livre arbítrio ou liberdade resulta de um plus ou de um minus em relação à natureza? A liberdade pode ser vista como algo sublime que assemelha o ser humano a Deus e o torna superior aos demais seres. Mas todas essas características humanas também podem ser pensadas, cética ou biologicamente, como um 'defeito' no código genético, gerando inadaptação ao mundo e conflitos, inexistentes entre abelhas e formigas". ${ }^{3}$

Vê-se facilmente como a concepção da filosofia como retórica, mais modesta, vai levar a diferenças relevantes no que concerne à teoria do conhecimento e à postura ética diante do mundo.

A retórica também poderia ser dita um método filosófico, mas essa afirmação estaria incompleta na medida em que outra tese aqui é exatamente tentar mostrar que a retórica, além de método, consiste também de uma metodologia e de uma metódica, para isso tomando por base a distinção entre retórica material, prática e analítica, que será discutida adiante.

Tenta-se assim cooperar para combater um equívoco bem difundido, não apenas entre o vulgo, mas também no meio filosófico, qual seja, o de que retórica é

\footnotetext{
${ }^{3}$ ADEODATO, João Maurício. Filosofia do direito - uma crítica à verdade na ética e na ciência, 3 . ed. rev. e ampl. São Paulo: Saraiva, 2005, p. 235 s. Todo o livro trata dessa dicotomia.
}

Revista Seqüiência, no 56, p. 55-82, jun. 2008. 
exclusivamente ornamento e estratégia para influir na opinião dos incautos. Mesmo considerando a importância dessa sua função, a retórica vai muito além dela e pode servir como instrumento para situar o ser humano de modo mais adequado no mundo, tanto no que concerne ao conhecimento quanto naquilo que diz respeito ao relacionamento com os demais seres humanos.

Tal modo de abordagem presta-se a análise em filosofia do direito e em outros campos discursivos, inclusive no estudo dos paradigmas das ciências biológicas e matemáticas, pois descreve uma situação do próprio conhecimento humano e de sua linguagem. Também a ciência é um meta-acordo lingüístico sobre um ambiente lingüístico comum, o qual também é acordado.

Aquelas duas inclinações (ontológicas e retóricas) que vão marcar a cultura ocidental revelam-se desde cedo no radicalismo das oposições na Grécia antiga: para Parmênides, nada muda, pois o movimento é uma ilusão e o conhecimento, imanente, sua garantia já está no ser humano; para Heráclito, tudo muda e só a mudança tem caráter permanente, sendo esse mundo exterior em mudança o ponto mais firme para o conhecimento, que é transcendente, pois "tudo passa, nada permanece" (ðÜîóá ñåé i̇ýäåí iÝiåá - pánta rei oúden ménei - na síntese tardia de seu pensamento).

O grau de originalidade e afirmação de certeza das diversas correntes que exprimiram essa oposição na filosofia é extremamente variável, mas pode-se dizer que os racionalistas vêm confrontando os empiristas pelo menos até Descartes e Locke e que as sínteses tentadas por Kant, Hegel e outros pensadores não resolvem a oposição.

Resta claro, nesse embate, que as ontologias têm prevalecido nas concepções filosóficas do Ocidente, de todo o mundo, sobretudo após a vitória dos monoteísmos e a defesa intransigente de sua própria verdade. Deixando de lado todo o viés retórico que acompanha a civilização ocidental desde a sofística, a autora afirma que "a filosofia é uma deliberação orientada por um valor: a verdade. É o desejo do verdadeiro que move a filosofia e suscita filosofias" ", exatamente interpretando uma frase de Kant que parece expressar o contrário: "Não se aprende filosofia, mas a filosofar". Não se trata, no caso, apenas da tradicional defesa platônica do critério da verdade: talvez a verdade seja mesmo corolário de uma necessidade atávica do ser humano por segurança, verdade na teoria do conhecimento, justiça na esfera ética.

No Ocidente, o domínio de uma forma de racionalismo, que culmina em Descartes, transparece nas diversas línguas, plenas de consoantes, que temperam as vogais, de controle mais difícil, diferentemente do que ocorre no chinês, por exem-

${ }^{4}$ CHAUÍ, Marilena. Convite à filosofia. São Paulo: Atica, 2003, p. 88. 
plo. Temperam no sentido musical técnico mesmo. Como as consoantes, os instrumentos e a música do ocidente "racionalizam" os sons exatamente temperando-os, o que significa "definindo-os", seja por meio dos dedos do violinista, da afinação do piano ou das formas de partituras, tonais a dodecafônicas. Por isso a música oriental soa "indefinida" aos ouvidos ocidentais. Já as consoantes temperam com os dentes, a língua, os lábios, o palato.

Conhecendo esse ambiente há também motivos estratégicos para a defesa da verdade, pelo menos entre os juristas práticos, que escondem o caráter retórico de sua profissão para fortalecer os próprios argumentos. Ao defender uma "verdade da lei e dos fatos", sem reconhecer que se trata de "meras" opiniões, o jurista apresenta-se como "teórico" ou cientista e não como doutrinador ou dogmático5.

A retórica surge ligada à sofística e herda o preconceito contra ela, o qual leva a sua identificação com a erística, colocando em um mesmo plano entimemas e erismas $^{6}$. Mais correto é ver o erisma como um dos tipos de encadeamento de juízos, de argumentos sofísticos. O fato é que poucos círculos filosóficos causam tanto debate e controvérsia como o da sofística. Seus defensores ora são vistos como politicamente "de esquerda", ora como "de direita", desde os sofistas clássicos, que se contrapunham a Sócrates, Platão e Aristóteles, até os céticos contemporâneos. São, por um lado, considerados sintoma e mesmo causa da decadência da Polis grega e, por outro, progressistas, modernos, até iluministas. Relativistas, niilistas, agnósticos, individualistas, céticos e positivistas são alguns dos epítetos aplicados aos sofistas, todos com fundamento ${ }^{7}$.

Este texto começa com as bases sofísticas e aristotélicas da retórica na Grécia antiga, mostra sua evolução diante da inserção das concepções filosóficas do historicismo, do ceticismo e do humanismo, para, finalmente, tentar desenvolver criativamente a concepção tripartida da retórica sugerida por Ottmar Ballweg a partir da obra de Charles William Morris.

\footnotetext{
${ }^{5}$ BALLWEG, Ottmar . Phronetik, Semiotik und Rhetorik, in: BALLWEG, Ottmar; SEIBERT, ThomasMichael (Hrsg.). Rhetorische Rechtstheorie. Freiburg-München: Alber, 1982, p. 38-39.

${ }^{6}$ ADEODATO, João Maurício. O silogismo retórico (entimema) na argumentação judicial, in: ADEODATO, João Maurício. Ética e retórica - para uma teoria da dogmática jurídica, 3. ed. rev. e ampl. São Paulo: Saraiva, 2007, p. 325 s.

${ }^{7}$ KIRSTE, Stephan. Einleitung, in: KIRSTE, Stephan; WAECHTER, Kay; WALTHER, Manfred (Hrsg.). Die Sophistik - Entstehung, Gestalt und Folgeprobleme des Gegensatzes von Naturrecht und positivem Recht. Stuttgart: Steiner, 2002, p. 7-16. GAST, Wolfgang. Die sechs Elemente der juristischen Rhetorik: Das Modell rhetorischer Kommunikation bei der Rechtsanwendung, in: SOUDRY, Rouven (Hrsg.). Rhetorik - Eine interdisziplinäre Einführung in die rhetorische Praxis. Heidelberg: C. F. Muller Verlag, 2006, p. 30. GUTHRIE, W. K. C. The sophists. Cambridge: Cambridge University Press, 1991, p. 51.
} 
Deve-se insistir que a intenção não é expor o pensamento desses autores, não se trata exatamente de suas definições, pois não se pode dizer que endossariam os inúmeros adendos e complementações feitas à sua revelia. Ainda assim, os traços centrais da retórica jurídica analítica sugerida por Ballweg servem como um marco teórico central deste artigo, ao lado de outros, a exemplo da metódica estruturante de Friedrich Müller, da ética da tolerância e do ceticismo pirrônico.

\section{Os fundamentos: ethos, pathos e logos}

Essas três expressões são utilizadas na Retórica de Aristóteles como meios de persuasão na comunicação e compõem a auto-apresentação dos oradores: "A primeira espécie depende do caráter pessoal do orador; a segunda, de provocar no auditório certo estado de espírito; a terceira, da prova, ou aparente prova, fornecida pelas palavras do discurso propriamente dito"s. Vão impregnar toda a terminologia retórica posterior e precisam ser rapidamente explicitadas aqui para que se compreenda o que significa a atitude retórica.

O grande problema, comum quando se estudam temas e expressões de tamanha longevidade e importância, é o alto grau de porosidade lingüística das palavras; ao longo de tantos anos, há intersecções, diferenciações, traduções ou simplesmente confusões entre os termos.

Em Aristóteles é colocada claramente a junção entre retórica e virtude moral, fazendo o ethos acompanhar a virtude (areti) e a ponderação ou prudência (phrónçsis), muito embora o caráter necessário dessa correlação tenha sido questionado desde o início, debatendo os eruditos sobre diferentes critérios para separação conceitual entre ethos, aretì e phrónçsis. Da mesma maneira que Aristóteles insiste para que a retórica não possa ser usada sem uma boa ética, opiniões contrárias vêem a retórica como um instrumento para quaisquer fins. Exatamente a presença dessa controvérsia atesta o problema da relação milenar entre retórica e ethos.

Etimologicamente, a palavra ethos já parece trazer uma confluência ou evolução de duas palavras gregas, semelhantes, mas distintas: de um lado ÅĖİÓ (Ýèìò, éthos), significando "costume", "uso", "hábito", e de outro ÇĖİÓ (Pèìò, ìthos), significando "caráter", "forma de pensar". No grego arcaico um termo não se distinguia do outro 9 . Depois da diferenciação, porém, ainda hoje se percebem esses dois sentidos na palavra ética: um social e um pessoal.

\footnotetext{
${ }^{8}$ ARISTOTLE. Rhetoric. Trad. W. Rhys Roberts. Col. Great Books of the Western World. Chicago: Encyclopaedia Britannica, 1990, v. 8, I, 2, 1356a1-5 e 14-16, p. 595.

${ }^{9}$ PELLEGRIN, Pierre. Le Vocabulaire d'Aristote. Paris: Ellipses, 2001, p. 23 s.
} 
O ethos designava, assim, um caráter que é resultado do hábito, que se percebe na aparência, nos traços, nas características, no olhar, no porte. Inicialmente, com esse sentido mais físico, é o lugar onde se tem o hábito de viver (habitar), a que se está acostumado, inclusive os animais; aí passa a designar uso, costume, maneiras; uma terceira acepção é a de disposição de caráter, no sentido de inclinação a determinadas atitudes e escolhas humanas, como ter um ethos sonhador, colérico ou melancólico; e um quarto, talvez posterior, refere-se à impressão produzida por um orador nos circunstantes, o que já vai se aproximar do sentido de pathos $^{10}$.

A palavra "ética" já vem significar o conjunto de conhecimentos relacionados ao ethos. Mas não é apenas a doutrina ou disciplina para estudo do ethos, mas também esse próprio ethos, no sentido de designar simultaneamente a meta-linguagem (estudo do caráter humano) e a linguagem-objeto (o caráter humano, tal como ele se apresenta). Outros autores preferem denominar essa ética-objeto de "moral", reservando a expressão "filosofia moral" para o conhecimento do objeto" .

É importante reter que, no plano da meta-linguagem, processou-se mais uma diferenciação: "ética" expressa, de um lado, o estudo dos fins que efetivamente guiam a conduta e dos meios que conduzem a esses fins, todos chamados "valores"; de outro, refere-se ao estudo das maneiras de controlar e guiar esses meios e fins. Para dar um exemplo, pela primeira perspectiva, o conhecimento ético mostra que indivíduos inseguros tendem a se aproximar de bajuladores; pela outra, que tanto bajuladores como inseguros devem ser evitados (ou louvados, dependendo da ética). A primeira é a ética descritiva, a segunda, a prescritiva.

Um dos bons argumentos a favor da ética prescritiva como perspectiva gnoseológica (plano da meta-linguagem) mais adequada é que a abordagem descritiva já está a cargo da sociologia, da antropologia, da psicologia e demais ciências ${ }^{12}$.

Para desviar do problema, incluindo todos os planos, vai-se aqui fazer a equivalência entre esses dois sentidos tradicionais da expressão "ética" (meta-linguagem e linguagem-objeto), um dos quais (meta-linguagem) se subdivide em mais dois (ética descritiva e prescritiva) - o que resulta em três acepções -, sugerindo outra tripartição: retóricas material, prática e analítica.

Pathos, plural páthç, significa paixão, emoção, sentimento. Fora dos círculos filosóficos, a expressão era usada na linguagem comum e designava qualquer forma de sentimento, mais no sentido de sofrimento, em oposição a "fazer" ativa-

\footnotetext{
${ }^{10}$ LIDDEL, Henry George e SCOTT, Robert (comp.). A Greek-English Lexicon. Oxford: Clarendon Press, 1996, p. 480 e p. 766. BAILLY, Anatole. Dictionnaire Grec Français (rédigé avec le concours de E. Egger). Paris: Hachette, 2000 (27. ed.), p. 581 e p. 894.

${ }^{11}$ CHAUÍ, Marilena. Convite à filosofia. São Paulo: Ática, 2001, p. 339 s.

${ }^{12}$ NERI, Demétrio. Filosofia moral - manual introdutivo. Trad. Orlando Soares Moreira. São Paulo: Loyola, 2004, p. 27-29.
} 
mente. Na Retórica de Aristóteles, o pathos está associado ao ouvinte e o ethos ao orador, ainda que essa associação tenha diminuído e até desaparecido em autores posteriores. O conceito de pathos firma-se para designar qualquer emoção de dor ou alegria, por meio da qual as pessoas se modificam de tal modo que suas decisões se tornam diferentes do seu estado habitual. No Renascimento, a retórica do pathos é sistematizada como parte da tópica, reunindo os denominados "argumentos patéticos".

Mas, além de significar esses estados d'alma, pathos designa a expressão ou articulação desses sentimentos e também, o que mais interessa como sentido retórico, indica uma qualidade do discurso, que consiste em despertar no ouvinte os mesmos sentimentos que o orador deseja transmitir. Aí está o ponto mais importante: o pathos que desperta o pathos por artes da retórica. Essa transmissibilidade patética do discurso se dá quando o orador consegue uma disposição contrária àquilo que quer atacar (indignação, deeiinosis, indignatio) ou adesão àquilo que quer defender (compaixão, comiseração, eleeinologia, miseratio).

A importância dada ao pathos pelos oradores parece ter sido muito grande na retórica sofística ao tempo de Aristóteles, pois ele faz críticas aos discursos excessiva ou exclusivamente circunscritos ao pathos. Mesmo assim, em sua ética, apesar de os sentimentos serem considerados irracionais, Aristóteles destaca a importância do pathos e vê uma relação estreita entre pathos e ethos, pois os "afetos" precisam ser controlados pela virtude do caráter e alcançar um meio-termo desejável racionalmente, prudentemente, a metriopatia entre os extremos maléficos das paixões, pois “...a virtude refere-se a paixões e ações, nas quais o excesso é uma forma de fracasso..."13.

Hoje, o adjetivo "patético" ainda mostra a vitória desse controle apolíneo, de Aristóteles a Kant, aparecendo sempre com sentido excessivo, pejorativamente. Isso porque, como já advertia a retórica antiga, embora sem as ilações de Aristóteles, o grande perigo do pathos é o exagero, é transformar a indignação ou a compaixão em afetação. Isso torna o pathos vazio, torna-o bathos.

Essa ligação entre pathos e ethos, em Aristóteles, está no contexto de considerá-los formas de persuasão retórica, ao lado do logos, como dito. E os raciocínios demonstrativos do logos não tinham o prestígio que a ciência "lógica" lhes veio emprestar na modernidade. Há uma consciência clara, já na Grécia antiga, de que certos assuntos humanos, assim como determinados tipos de auditório, pouco têm a fazer com a razão "lógica". Mesmo assim, essa razão analítica, tal como entendida hoje, de caráter cogente, constituía apenas um dos aspectos da palavra.

\footnotetext{
${ }^{13}$ ARISTOTLE. Nichomachean Ethics. W. D. Ross. Col. Great Books of the Western World. Chicago: Encyclopaedia Britannica, 1990, v. 8, II, 5-6, 1106b20-25, p. 352.
} 
O termo logos, plural lógoi, passou a ser traduzido como "razão" ou "ciência", mas originalmente parece ter significado "linguagem". O primeiro sentido de logos (na forma verbal légein) é falar, dizer, designando a princípio apenas o próprio ato, mas depois também o resultado da ação, ou seja, a fala mesma. A segunda conotação adquirida pela palavra é a de reunir, colecionar, como em katálogos. Esses sentidos permanecem ligados à palavra logos desde seu aparecimento, assim como os de razão, argumentação, definição, pensamento, verbo, oração etc., muitos deles com freqüente emprego na retórica ${ }^{14}$.

O sentido de logos guarda certa oposição com o de érgon, que significa resultado, efeito, efetividade, realidade, e é atualmente utilizado por Ballweg, como se verá adiante. A distinção entre logos e érgon aparece em Anaxágoras e os sofistas a fazem equivaler àquela entre nomos e physis, respectivamente, emprestando assim um caráter também normativo ao logos. Só depois surge a lógica na acepção atual, mas fica competindo com vários outros sentidos durante longo tempo. Observe-se ainda que o estudo metódico do pensamento racional-dedutivo é chamado por Aristóteles de analítica e não de lógica, expressão utilizada para a arte da disputa argumentativa; para o filósofo, é a analítica e não a lógica que se opõe à retórica. Na mesma direção, sofistas como Isócrates definiam a retórica como a arte do logos.

Em outras palavras, logos é linguagem em sentido performático, com todas as suas estratégias e matizes, não designa apenas o sistema de regras dirigentes do pensamento. Só posteriormente separaram-se o logos lógico da "razão" e os âmbitos da opinião, da percepção e do mito. Por isso Protágoras já defendera o dissoi logoi, afirmando que, em qualquer tema, é possível manter opiniões contrárias. Daí porque todas as coisas são ao mesmo tempo boas e más, justas e injustas, verdadeiras e falsas.

Esse é o logos da retórica.

\section{Da sofística à retórica: inserções de historicismo, ceticismo e humanismo}

Uma tese aqui é que a retórica nasce da sofística e torna-se mais extensa do que ela. Isso se deve a acréscimos, diferenças conceituais e novas atitudes que foram fornecendo à sofística inserções mais filosóficas, que a transformaram em retórica. As principais são as contribuições do historicismo, do ceticismo e do humanismo.

${ }^{14}$ UEDING, Gert (Hrsg.). Historisches Wörterbuch der Rhetorik, Band 5. Darmstadt: Wissenschaftliche Buchgesellschaft, 1994, p. 624 s. 
Essa visão não é de maneira alguma única. Para outros autores, o surgimento da retórica e da sofistica é paralelo, ficando a retórica com a reflexão sobre a linguagem e a sofística com a reflexão sobre o poder, o que se teria tornado o critério definitivo de sua separação ${ }^{15}$.

Esse processo toma grande impulso com a "virada" humanista, também chamada de socrática, depois da qual a filosofia passa a se ocupar mais do ser humano e da ética do que do cosmos, modificando a tradição pré-socrática dos filósofos que procuravam uma ontologia da natureza, mais semelhantes aos modernos astrônomos e físicos. Essa mudança humanista não deve ser atribuída apenas a Sócrates, insista-se, mas também aos sofistas, que disputavam com os socráticos em torno das razões do bem e do mal.

Essas raízes antigas do humanismo passam para a República Romana, para o chamado "círculo cipiônico", descrito por Scipio Aemilianus (185-129 a.C.), e o studia humanitatis, conceito já presente em Cícero (106-143 a.C.). Mais longe ainda podem-se detectar suas origens em Heráclito, precursor já referido, que distingue o ser humano dos demais seres vivos por meio de razão e linguagem (logos), caráter distintivo de humanidade.

Primeiro, então, o historicismo, pois a história era considerada uma parte da retórica na Grécia Antiga e consistia nos relatos exemplares das condutas eticamente positivas ou negativas, aquelas condutas que poderiam fornecer exemplos para uma argumentação convincente. Esses exemplos históricos seriam, por isso mesmo, uma concretização da persuasão, um "argumentum auctoritatis feito carne". Aristóteles afirma que um argumento (entimema) baseado em um exemplo que as pessoas crêem ter realmente ocorrido é mais convincente do que quando não há essa crença.

Foi a revolução do racionalismo cartesiano que estabeleceu uma concepção etiológica e escatológica da história. A nova história passou a ser causal, vista como um estudo natural de causas e efeitos, a exemplo dos novos paradigmas da física e da biologia, assim como progressista, na medida em que supostamente se evolui para melhor. Começa-se a "fingir a hipótese de um nexo causal entre presente e passado, inclusive fazendo prevalecer o 'moderno' frente ao 'antigo', assentar a superioridade do presente, fruto do denodado esforço do homem". ${ }^{16}$

O historicismo da retórica é sisífico, procura ir contra essas perspectivas etiológica e escatológica. A história não deve ser pensada em termos causais nem

${ }^{15}$ BALLWEG, Ottmar . Phronetik, Semiotik und Rhetorik, in: BALLWEG, Ottmar; SEIBERT, ThomasMichael (Hrsg.). Rhetorische Rechtstheorie. Freiburg-München: Alber, 1982, p. 33.

${ }^{16}$ GIL CREMADES, Juan José e RUS RUFINO, Salvador. Estudio preliminar, in THOMASIUS, Christian. Historia algo más extensa del derecho natural. Madrid: Tecnos, 1998, p. IX-XLVII, p. $\mathrm{X}-\mathrm{XI}$. 
caminha para algum ponto previamente determinável, exatamente porque os consensos temporários de sentidos são circunstanciais e infinitamente variáveis, por vezes contraditórios. Assim como Sísifo não sabe até onde, montanha acima, conseguirá transportar a pedra, a humanidade não sabe aonde vai chegar. E cada tempo histórico é construído a cada momento ${ }^{17}$.

Nem na Europa medieval, com toda a preponderância de Platão e da parte ontológica de Aristóteles, a retórica foi tão desconsiderada como no início da modernidade, pela nova mentalidade cartesiana, exatamente para combater o historicismo e o humanismo renascentista que haviam ressuscitado com toda força as fontes filosóficas da retórica antiga. A modernidade é esse hiato, que torna a retórica ainda mais marginal, até a "virada lingüística" do século XX, quando recomeça alguma atenção às perspectivas retóricas.

A crítica e a mudança de paradigmas a que a modernidade vai submeter esse domínio temporário do humanismo, que se instalara ao longo do Renascimento, já são antecipadas por Mulcaster, em 1580, e por Francis Bacon, pregando uma maior dedicação às ciências naturais, reclamando de uma educação excessivamente retórica. Algum tempo depois, com o racionalismo cartesiano e hobbesiano, a nova mentalidade estava instalada no Ocidente e a história deixa de ser vista como registro de relatos exemplares e passa a ser concebida como "causal", reveladora de nexos "naturais" entre fatos. Até hoje.

Mas o humanismo já se incorporara à retórica. Uma das principais obras de estudo era a Rhetorica ad Herennium, atribuída a Cícero, mas depois questionada em sua autenticidade. A visão taxonomista da obra, assim como a de muitas outras do gênero, pode ser exemplificada pelas partes fundamentais do discurso, presentes nas obras sobre retórica: inventio (criar a plausibilidade do argumento), dispositio (organizar as informações), elocutio (adequar o pensamento a sua formas de expressão), memoria (reter a informação) e pronuntiatio (contenção, postura da voz, sobriedade, elegância no falar ou escrever) ${ }^{18}$.

As classificações e critérios, contudo, variam muito, podendo-se falar nessas partes como "estágios de produção do discurso", reservando a denominação de partes orationis para exordium, narratio, argumentatio e conclusio ou peroratio, cujos detalhes não interessam aqui ${ }^{19}$. São apenas citados para exemplificar algo do currículo humanista.

\footnotetext{
${ }^{17}$ ADEODATO, João Maurício. Ética e retórica - para uma teoria da dogmática jurídica, 3. ed. rev. e ampl. São Paulo: Saraiva, 2007. Sobre Sísifo, p. 266; sobre a etiologia, p. 391 s.

${ }^{18}$ A obra continua sendo publicada integrando as de Marco Túlio Cícero. Retórica a Herennio. Obras Completas de Marco Tulio Cíceron (em 16 tomos). Madrid: Librería y Casa Editorial Hernando, 1928 , tomo III.
} 
Retórica é ornamento, sim, mas não apenas ornamento. Ornatus é a qualidade do orador que coroa o discurso e a palavra é a mesma empregada no estar preparado para a batalha. Observe-se a expressão "ornado" e não "ornamentado". Essa "armadura" consiste do conjunto de qualidades que compõem o estilo, a habilidade culminante do grande orador ${ }^{20}$. A Retorica ad Herennium compara literalmente a eloqüência a uma arma poderosa para aniquilar os inimigos.

Já antes de Quintiliano a retórica se divide em uma teoria da argumentação, tópica, e uma teoria das figuras, mais formal. É curioso notar como a ênfase sobre o ornamento parece vir mais dos adversários do que propriamente dos retóricos. Claro que isso não desmerece a estratégia do ornamento, mas a importância da tópica como "conteúdo" persuasivo do discurso mostra que o formalismo radical, basicamente classificatório e exclusivamente dedicado a essas figuras de estilo, de que por vezes são acusados os discípulos de Quintiliano, não resiste a uma análise mais acurada.

Paradigmática a respeito é a visão de um desses discípulos, por volta de 1815, no Recife: Frei Caneca não reduz a retórica a uma teoria de figuras e estilos, simplificação até hoje difundida; mantém-se fiel a Aristóteles e considera também os aspectos tópicos da retórica. Com efeito, a inseparabilidade entre a análise formal das figuras de linguagem e o conteúdo argumentativo, que o orador deseja transmitir, é sempre enfatizada. Se os motivos em uma peroração podem ser éticos ou patéticos, por exemplo, a escolha precisa ter como critério e fundamento a finalidade tópica daquele discurso e o "devido decoro" precisa levar em consideração “...a pessoa do proprio orador; as pessoas dos seus ouvintes; e as pessoas ácerca das quaes versa o seu discurso"21. Tais considerações são tópicas no sentido de que os conteúdos persuasivos só serão preenchidos por lugares-comuns, válidos para aquele ambiente discursivo, aquele contexto retórico, precariamente generalizáveis e de difícil controle.

O humanismo vem preencher a tópica de conteúdo ético e Frei Caneca é apenas um dentre vários autores a ir nessa direção. Essas duas ênfases convergentes de ver o mundo, historicista e humanista, receberam extraordinário impulso com a invenção da imprensa por Johannes Gutenberg, em Mainz, tornando muito mais difícil destruir todos os exemplares de um livro e fazer calar idéias.

\footnotetext{
${ }^{19}$ UEDING, Gert. Was ist Rhetorik?, in: SOUDRY, Rouven (Hrsg.). Rhetorik-Eine interdisziplinäre Einführung in die rhetorische Praxis. Heidelberg: C. F. Muller Verlag, 2006, p. 13-23.

${ }^{20}$ SKINNER, Quentin. Reason and rhetoric in the philosophy of Hobbes. Cambridge: Cambridge University Press, 1996, p. 49 s.

${ }^{21}$ CANECA, Frei Joaquim do Amor Divino. Tratado de eloqüência. In: Obras políticas e literárias (colecionadas pelo Comendador Antonio Joaquim de Mello). Recife: Typographia Mercantil, 1875 (ed. fac simile, 1972, p. 63-155), p. 69, 77 e passim.
} 
A perspectiva retórica não se pode embasar nas certezas subjetivas, na razão solipsista do método cartesiano. Linguagem implica convivência, pois não há comunicação em isolamento. Implica pluralidade e, assim, relativização das concepções de verdade, pois os seres humanos percebem diferentemente a realidade. Ao contrário das correntes filosóficas dominantes - ontologias essencialistas ou convencionalistas, histórico-escatológicas e evolutivas -, as quais imaginam o conhecimento e a ética como em alguma medida absolutos e independentes da linguagem, ou fruto de um desenvolvimento histórico objetivista, o humanismo defende que o conhecimento só é possível dentro da linguagem e do relativismo que ela necessariamente traz. Logo, é retórico.

Faltam, então, algumas palavras sobre o ceticismo, cuja ligação com o historicismo também é forte. Os processos históricos são pensados por meio de conceitos amplos que se expressam em palavras, porque não há outro jeito; porém, muito mais que "meras" palavras designativas de objetos, os processos históricos simplesmente não podem ser definidos. Diz Nietzsche, visionário da "virada lingüística" de Wittgenstein, que só aconteceria no século XX: "Todos os conceitos nos quais se compõe semioticamente um processo inteiro escapam à definição; definível é somente aquilo que não tem história." ${ }^{22}$

A perspectiva histórica traz, assim, um componente cético, uma resignação diante da impossibilidade de compreender de forma definida qualquer coisa que se processe na historia, que "tenha" história, como diz Nietzsche. O que é humano modifica-se ao longo da história e isso só pode ser compreendido sob perspectiva relativa: relativa às preferências dos participantes, aos consensos lingüísticos, às capacidades de causar dano ao outro, de distribuir vantagens, em suma, ao ambiente da comunicação.

Tomando lições do ceticismo pirrônico, duas atitudes que podem conduzir a esse relativismo cético são uma isostenia no campo gnoseológico e uma ataraxia no campo ético. Isostenia significa procurar suspender quaisquer juízos definitivos, o que leva a uma visão de mundo e a um estado de espírito que os céticos consideram desejável. Isso se consegue ponderando os lados diversos das controvérsias, concluindo pela "igual força" (literalmente isostenia) dos argumentos. Assemelhase ao dissoi logoi de Protágoras, já referido: toda controvérsia tem lados diversos e não há um lado "certo".

Ataraxia significa imperturbabilidade, pois a expressão constrói-se pela negação da taraché, a perturbação que traz infelicidade. A adiaforia, então, valor importante para o cético, consiste na convicção de que as coisas e acontecimentos

${ }^{22}$ NIETZSCHE, Friedrich. Zur Genealogie der Moral - Eine Streitschrift. in COLLI, Giorgio MONTINARI, Mazzino (Hrsg.): Friedrich Nietzsche Kritische Studienausgabe - in fünfzehn Bände, vol. 5. Berlin: Walter de Gruyter, p. 245-424 (II, 13, p. 317). 
são indiferentes para com os seres humanos e que o acaso, o azar e a fortuna são parte da vida, pois a "racionalidade" está no ser humano e não no mundo. Esses estados de espírito, por assim dizer, contribuem para a idéia de moderação, ou metriopatia, já mencionada, ideal também pregado pelos estóicos e epicuristas. Ser cético não implica estar completamente livre das perturbações inevitáveis da vida; mas considerá-las más ou contrárias aos apetites humanos não é razoável e torna mais difícil a ataraxia.

Esses conceitos também já foram debatidos com mais detalhes em outro lugar ${ }^{23}$.

Resumindo, a sofística constitui o primeiro movimento retórico na história do pensamento ocidental. A corroborar a tese de que sofística também é filosofia, notese que é justamente a passagem do mito à filosofia, pela qual a pretensão de racionalidade vem se confrontar à de crença, que atesta a divisão da filosofia entre as sofísticas e as ontologias da verdade. As religiões, é claro, vêm em apoio dessas últimas, mormente os grandes monoteísmos e suas cosmologias exclusivistas.

Esquema 1: evolução histórica da retórica

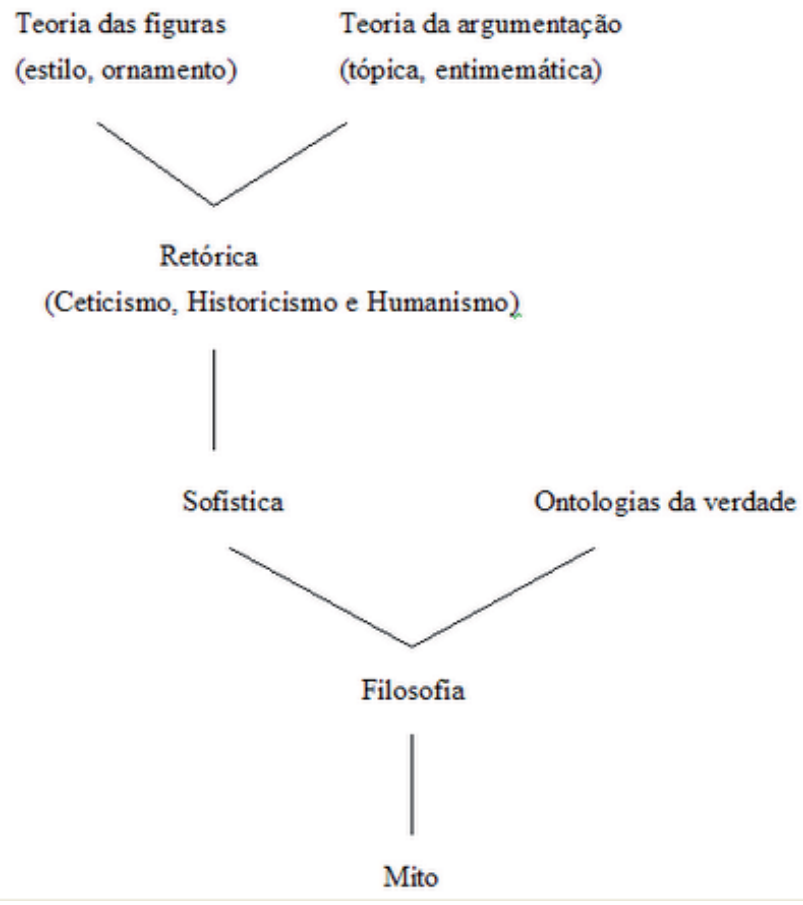

\footnotetext{
${ }^{23}$ ADEODATO, João Maurício. Pirronismo, direito e senso comum - o ceticismo construtor da tolerância, in: ADEODATO, João Maurício. Ética e retórica - para uma teoria da dogmática jurídica, 3. ed. rev. e ampl. São Paulo: Saraiva, 2007, p. 377 s.
} 
Assim, o conceito de retórica é complexo e modificou-se muito ao longo da história, o que dificulta sobremaneira sua definição. Mas tanto a retórica quanto a doutrina jurídica (no sentido de uma visão mais especializada do direito, da jurisprudência ou "ciência" do direito) parecem ter nascido da sofística. A retórica se bifurca em uma teoria das figuras e do estilo (sentido formal estrito), a retórica-ornamento, e uma teoria da argumentação de estrutura entimemática (claro que não de estrutura racional-dedutiva, como as teorias da argumentação contemporâneas de Habermas e Alexy), a retórica-tópica, também entendida pelos gregos antigos como um dos sentidos de "dialética".

Aristóteles definia o conceito de "tópica" como o conjunto de lugares-comuns que constituiria um dos fundamentos dos argumentos entimemáticos, ao lado do paradigma, por exemplo. Modernamente, na esteira do pensamento de Viehweg, a tópica passa a ser vista como uma dessas duas subdivisões da retórica, ao lado da teoria das figuras; para outros tópica e retórica são sinônimos, em oposição à "lógica" e à "filosofia". ${ }^{24}$

Segundo outros registros respeitáveis, em certo ponto da Antiguidade grega a palavra "dialética" passou a ser usada como sinônimo de "lógica", identificação que passa pela Idade Média e perdura até a modernidade. Tal sentido dessas palavras não é, porém, unânime, encontrando adversários como Kant e Schopenhauer, os quais, mais etimologicamente, associam a dialética à retórica e à sofística, como "a arte de disputar", unindo a lógica às regras a priori do pensamento puro ${ }^{25}$. Esse entendimento parece ter hoje se firmado como dominante.

\section{Três dimensões da retórica: retórica como método, metodologia e metódica}

Deixando de lado o termo "dialética", que em cada pensador parece ter sentido diferente, entenda-se aqui "retórica" em três acepções principais: ${ }^{26}$

\footnotetext{
${ }^{24}$ VIEHWEG, Theodor. Topik und Jurisprudenz - Ein Beitrag zur rechtswissenschaftlichen Grundlagenforschung. München: C. H. Beck, 1974 (4. Aufl.). SCHLIEFFEN, Katharina von. Rhetorische Analyse des Rechts: Risiken, Gewinn und neue Einsichten, in: SOUDRY, Rouven (Hrsg.). Rhetorik - Eine interdisziplinäre Einführung in die rhetorische Praxis. Heidelberg: C. F. Muller Verlag, 2006, p. 42-64.

${ }^{25}$ SCHOPENHAUER, Arthur. Eristische Dialektik, in: SCHOPENHAUER, Arthur. Sämtliche Werke, 6. Band. DEUSSEN, Paul (Hrsg.). München, 1923, p. 391-428.

${ }^{26}$ Para esse conceito de retórica tenta-se aqui detalhar mais a sugestão de BALLWEG, Ottmar . Phronetik, Semiotik und Rhetorik, in: BALLWEG, Ottmar; SEIBERT, Thomas-Michael (Hrsg.). Rhetorische Rechtstheorie. Freiburg-München: Alber, 1982, p. 27-71; BALLWEG, Ottmar. Entwurf einer analytischen Rhetorik. In: SCHANZE Helmut e KOPPERSCHMIDT, Joseph (Hrsg.). Rhetorik
} 
A retórica material, existencial, são as próprias relações humanas, entendidas todas enquanto comunicação, que constituem o primeiro plano da realidade: é a maneira pela qual os seres humanos efetivamente se comunicam, suas artes e técnicas sobre como conduzir-se diante dos demais, tecendo o próprio ambiente em que acontece a comunicação. A retórica material é "natural" no sentido de que se dá imediatamente, antes de qualquer reflexão, ela faz parte da própria condição antropológica, é o "dado ôntico" da sociabilidade humana, no sentido de uma comunicação "real".

Isso significa que conhecer apenas relatos sobre "o" mundo é a condição antropológica da retórica ou a condição retórica da "natureza" humana. O conhecimento não pode ser isoladamente obtido, como queriam Sócrates e Descartes. Depende da intersubjetividade. Aí se verifica que toda comunicação intersubjetiva é retórica, quer dizer, o ser humano, mais do que um animal racional, é um animal retórico.

Até a comunicação intrasubjetiva, o diálogo consigo mesmo que caracteriza o pensamento, é retórico. Quando as pesquisas sobre o cérebro humano "mapeiam" suas "regiões" e "reações químicas a estímulos", com todas as máquinas e métodos possíveis, isso consiste tão somente de consensos comunicativos temporários que se transmitem por relatos. Os eletrocardiogramas, o bombardeio de elétrons e as doenças mentais são partes desses relatos que constituem a "vida" humana.

Assim, a retórica material é o que se poderia conceder ser a única "condição ontológica" da antropologia. Quer dizer, o ser humano só pode ser concebido dessa perspectiva, sem a retórica material não é humano. Trata-se da própria condição lingüística da espécie, voltada para si mesma em um universo de signos e sentidos.

Hermann Cohen diz que "somente o pensamento é capaz de produzir o ser". ${ }^{27}$ A linguagem, não o "pensamento" como conceito metafísico, produz "o ser" de forma bem literal. Nesse sentido da retórica material, não há diferença entre os quasares e os buracos negros, de um lado, e os anjos e demônios medievais e contemporâneos, de outro. O ser humano hoje vive e crê em carros, árvores e arranha-

und Philosophie. München: Wilhelm Fink, 1989, p. 15-42; e BALLWEG, Ottmar. Rhetorik und Vertrauen. In: DENNINGER, E., HINZ, M., MAYER-TASCH, P. e ROELLECKE, G. (Hrsg.). Kritik und Vertrauen - Festschrift für Peter Schneider zum 70. Geburtstag. Frankfurt a.M.: Anton Hain, 1990. Trad. bras. João Maurício Adeodato. Retórica analítica e direito. Revista Brasileira de Filosofia, n. 163, fasc. 39. São Paulo: Instituto Brasileiro de Filosofia, 1991, p. 175-184. ${ }^{27}$ COHEN, Hermann. Logik der reinen Erkenntnis, Helmut Holzhey (Hrsg.). Werke Bd. 6, 1. Teil (System der Philosophie). Hildesheim/New York: Georg Olms Verlag, 1977. Também R. VANCOURT: Préface à trad. francesa da Métaphysique de la Connaissance de Nicolai Hart-mann. Paris: Aubier, p. 18 s. 
céus; da "realidade" medieval (com fiéis descendentes hoje), além de animais e pessoas, fazem parte do mundo bruxas e predições. É por isso que um juiz contemporâneo não aceitaria na lide argumentos baseados em viagens no tempo e cidadãos na Europa medieval não compreenderiam histórias sobre viagens em foguetes e aviões. $\mathrm{O}$ importante é a crença no relato, e essas relações comunicativas fazem a retórica material.

Hoje vírus e contaminações são tema de todo tipo de relatos discursivos, ainda que poucas pessoas saibam algo a respeito. Quase todos conhecem absolutamente nada sobre os critérios e dados empíricos que levaram à determinada informação (relato). Da mesma maneira, certos argumentos são tão complexos e exigem tantos pressupostos para ser discutidos que se tornam ineficazes, como ocorre na ciência. $\mathrm{O}$ que interessa mesmo é a crença retórica. Os constrangimentos discursivos desses consensos podem ser mais rígidos, como na ciência, mas a "realidade retórica" é a mesma.

O leitor já compreendeu que é irrelevante para os objetivos aqui se a predição, a teoria, a ideologia, a verdade científica foram ou não posteriormente "verificadas" na realidade, confirmação que, por sua vez, já é outro procedimento retórico, também sujeito a acordos fugidios, a outra transformação de paradigma científico, a outro relato qualquer.

Comunicar sobre algo é o que faz esse algo existir, eis a retórica material de Nietzsche.

Do ponto de vista do conhecimento, o subjetivismo contido na tradição da certeza cartesiana, no sentido de que a garantia da evidência seria a consciência subjetiva da experiência interna, com sua autocoerência, não mais subsiste depois da "virada hermenêutica" (ou lingüística), protagonizada por Wittgenstein, Heidegger e outros, os quais colocam como fonte primeira o conhecimento intersubjetivamente válido, proveniente do mundo exterior. O primado gnoseológico da experiência interna não pode prevalecer porque não há uma "verdade" subjetiva; a solução passa por um conteúdo de sentido no âmbito de uma linguagem comum a outras pessoas, na possibilidade de seguir, ou não, regras publicamente controláveis. Daí a indispensabilidade da pessoa do outro para a construção de qualquer sentido, qualquer comunicação ${ }^{28}$. Por isso "existem" demônios e buracos negros, id e ego, a invasão holandesa em Pernambuco.

\footnotetext{
${ }^{28}$ APEL, Karl-Otto. Wittgenstein und Heidegger: Kritische Wiederholung und Ergänzung eines Vergleichs, in: McGUINESS, Brian (Hrsg.). Der Löwe spricht... und wir können ihn nicht verstehen. Ein Symposion an der Universität Frankfurt anläßlich des hundertsten Geburtstags von Ludwig Wiittgenstein. Frankfurt a.M.: Suhrkamp, 1991, p. 27-68, p. 30-31.
} 
Esses controles públicos da linguagem são condicionais, temporários, autopoiéticos e circunstanciais; quanto mais complexo o meio social, mais se acentua esse caráter mutante e mais difícil estudá-los.

Mas essas dificuldades não podem ser resolvidas por intermédio de uma "coisa em si" como estímulo "real" ao conhecimento, à sensação, ao pensamento. Não só o conhecimento é retórico, a própria existência humana o é. Não parece haver "impressões", "percepções", nada que possa existir fora da linguagem, mesmo que seja a linguagem consigo mesmo que constitui o pensamento. Este é o pressuposto da retórica material. Realidade é comunicação, relatos sobre outros relatos, não há eventos "em si". Nem sequer se pode dizer que "a coisa em si é", como queria Kant, pois isso não faz sentido fora do preconceito etiológico, que precisa procurar uma causa primeira e não considera devidamente a autonomia dos acordos lingüísticos. E não apenas o pensamento conceitual funciona retoricamente, mas também o pictórico e todos os tipos de significados de todos os tipos de linguagem.

A perspectiva retórica sobre a qual se reflete aqui tampouco se assemelha ao entendimento de Berkeley, por exemplo, sobre o conhecimento humano, que não abandona o paradigma cartesiano. Berkeley sustenta que toda realidade é mental e que existir é o mesmo que ser percebido; mas ser percebido não significa apenas a percepção sensível (visão, audição olfato, paladar, tato). Os livros na gaveta, argumenta Berkeley, existem porque se pensa neles, se os imagina. $\mathrm{O}$ argumento é engenhoso, pois não se pode conceber quaisquer objetos sem a mente que os concebe, ou seja: não se pode pensar o impensado, essa é uma contradictio in terminis.

Mas Berkeley mantém pressuposições de ontologias da verdade, apesar de seu ceticismo. Há um subjetivismo solipsista, uma confiança no indivíduo com fonte do critério de conhecimento. A diferença para a concepção da retórica material é que esta parte do controle público da linguagem, a qual conduz aos consensos condicionais e temporários que constituem a comunicação.

A retórica material cuida dos "fatos", esses relatos intersubjetivos sobre outras relações comunicativas, elaborados segundo a percepção de cada um e em sua interação, sempre utentes com utentes (assim se chamam os "usuários", os participantes do discurso). Essa dimensão material corresponde aqui ao método. Os métodos são maneiras pelas quais efetivamente ocorre a comunicação no ambiente, as regularidades de conduta das pessoas, a conduta "real". Esse "real" consiste, por sua vez, de discursos retoricamente regulados, os relatos discursivos, os "fatos", isto é, descrições retóricas de estímulos, também lingüísticos, lingüisticamente percebidos.

A "matéria" inicial do conhecimento não é a coisa em si da estética transcendental de Kant, mas sim essa retórica. Os métodos são as formas, mais ou 
menos regulares, mediante as quais esses relatos, que fazem os seres humanos perceberem a realidade, se organizam. Todas as relações humanas com o ambiente se dão dessa maneira, seja o "natural", seja o social. Nesse nível não há reflexão, é a própria "realidade ôntica" da vida humana. A retórica material, existencial, é o conjunto de métodos de ação humana.

Dizer que a própria realidade é retórica significa também que a linguagem controla as relações humanas por meio de promessas, as quais podem ou não ser cumpridas, no todo ou em parte. Isso é real, controle na hora. Mas, por essa característica da razão humana, essas expectativas atuais têm como referência o futuro, que não existe, é apenas imaginado por meio de um discurso atual, este, sim, existente.

A retórica prática, ou estratégica, já é reflexiva, constitui um primeiro grau de meta-retórica, uma retórica sobre a retórica material, que parte dela e a ela retorna para reconstituí-la, isto é, interferir sobre ela. Para chegar a essa práxis, a retórica estratégica precisa de uma doutrina, uma teoria, aquele conjunto de regras, construídas a partir da observação da retórica dos métodos, que tem por objetivo influir sobre eles e possibilitar sucesso a quem deles se utiliza. Ela observa como funciona a retórica material e verifica que fórmulas dão certo, construindo uma pragmática finalística e normativa da comunicação. É literalmente uma metodologia (teoria dos métodos) da retórica material.

Trata-se de uma prática que pode ser ensinada, construindo uma doutrina a partir de experiências, observações e reflexões. Desse nível de retórica provêm a tópica, a teoria da argumentação, as figuras de linguagem e de estilo. Os discursos práticos são estratégias para modificar fatos (relatos da retórica material) e erigilos em objetos, isto é, fatos relativamente fixados, aos quais alguns relatos selecionados aderem, em detrimento de outros; os utentes os determinam, constituem esses objetos, transformando relatos de opiniões em objetos, que supostamente constituem as definições da linguagem de controle instituída, os relatos corretos, a verdade. A metodologia (Methodenlehre) é esse conjunto de estratégias que visam o sucesso, é uma visão sobre métodos que funcionam para determinados contextos e sobre como funcionam, uma teoria voltada para a práxis.

Essa retórica estratégica estuda que topoi aparecem mais freqüentemente em um discurso, os métodos empregados para esse ou aquele efeito, como os lugares-comuns retóricos são produzidos, utilizados, manipulados. Ela estuda o kairos, o momento adequado de dizer e fazer acontecer, ocupa-se da influência da linguagem, da gesticulação, das táticas empregadas e de seus efeitos sobre a retórica material, ou seja, sobre a conduta dos sujeitos, lançando mão de exercícios e reflexões sobre seus resultados. 
Finalmente, a retórica analítica procura ter uma visão descritiva e abstrairse de preferências axiológicas, mesmo diante de objetos valorativos. Diferentemente da estratégica, a retórica descritiva é formal, mas nunca normativa. Pode-se dizer, usando Viehweg, que a retórica analítica é zetética, a estratégica, dogmática. A retórica analítica procura ampliar a semiótica e dar igual atenção aos elementos signo, sentido ("objeto") e utente dentro dos sistemas lingüísticos, o que não é fácil: mas Ballweg reconhece que "essa dificuldade ela divide com a semiótica"29.

Dizer que a perspectiva analítica da retórica constitui uma metódica significa que, como ela se forma a partir dos dois níveis retóricos anteriores, não pode ser confundida com um método, no sentido de padrões de comunicação, nem com uma metodologia ou teoria do método, estratégias para controle e interferência sobre esses métodos (método-"logos"). A retórica metódica analisa a relação entre como se processa a linguagem humana e como as pessoas acumulam experiências e desenvolvem estratégias para utilizá-la de modo mais eficiente. Esse terceiro nível serve ao distanciamento necessário para compreender os outros dois.

Pensando mais especificamente no direito, Müller afirma que a metódica jurídica tem a tarefa de esclarecer as diversas funções e as formas de realização do direito (legislação, governo, administração, jurisdição, ciência do direito), diante de uma estrutura normativa geral e prévia e da necessidade de concretização da norma. A metódica pesquisa o trabalho prático dos órgãos e indivíduos que exercem essas funções; procura conceituar, definir, em suma, estruturar essas formas de realização (aqui chamados métodos, retórica material), por um lado, e as estratégias de que as pessoas envolvidas nessas formas lançam mão (a teoria dos métodos, metodologia), de outro ${ }^{30}$.

Método é o caminho (üäóò, odos), como se procede para atingir determinado objetivo. Metodologia é a doutrina sobre os métodos, isto é, a visão que se tem desses caminhos. Metódica é o estudo da relação entre esses métodos e essas metodologias para controlá-los.

No campo do direito, a metódica, analítica como se pretende, não se confunde com a lógica jurídica formal, ou com a disciplina "metodologia do direito" (a Methodenlehre adquiriu na doutrina alemã esse sentido bem próprio), nem com uma técnica de solução de casos. Menos ainda é um novo método, pois os métodos

\footnotetext{
${ }^{29}$ BALLWEG, Ottmar. Entwurf einer analytischen Rhetorik. In: SCHANZE Helmut e KOPPERSCHMIDT, Joseph (Hrsg.). Rhetorik und Philosophie. München: Wilhelm Fink, 1989, p. 19-20.

${ }^{30}$ Assim, para o conceito de metódica, aqui se aproveita e modifica, dando-lhe acepção retórica, uma idéia de MÜLLER, Friedrich. Juristische Methodik. Berlin: Duncker und Humblot, 1997, p. 25-36, e Métodos de trabalho em direito constitucional. São Paulo: Max Limonad, 2000, p. 21-23, p. 38 s. e p. $51 \mathrm{~s}$.
} 
são estudados pela metodologia e é essa relação que interessa à metódica, como dito.

Ver o nível analítico como uma metódica sugere ir além da metodologia e reconhecer que ele também tem como objeto os aspectos práticos da retórica. A força persuasiva ou enganadora da retórica estratégica, sobre a qual tanto se escreveu, não esgota a retórica, mas torna-se também objeto da própria retórica (analítica), esclarecendo uma dimensão revelada de quando em vez na história da filosofia, mas só agora estudada com mais ênfase. É a meta-linguagem (meta-linguagem de segundo nível ou meta-meta-linguagem) para observação das retóricas material e estratégica, sem o objetivo de influir sobre elas. Por ter essa preocupação desconstrutivista e analítica, procurando abster-se de atitudes valorativas, a postura metódica aqui pode ser chamada "desestruturante", em contraponto à teoria de Muller.

A metódica jurídica consiste numa teoria sobre a relação entre a teoria da prática (a metodologia, a doutrina dogmática, no caso do direito) e essa mesma prática (conjunto de métodos); procura uma meta-teoria, que veja o caso concreto em relação com as metodologias que o procuram conformar. A retórica analítica é descritiva, porque quer estudar, de modo mais desinteressado possível, essa influência que as metodologias (que são valorativas) exercem sobre os métodos (que também implicam escolhas axiológicas).

A argumentação estratégica se dirige a fins, busca produzir algum tipo de efeito. Mediante um discurso dirigido à persuasão, ela procura provocar acordo e aceitação. A conversa é uma oportunidade e a linguagem, uma ferramenta do orador para influenciar o ouvinte. Vem dessa função estratégica a acusação, que é feita à retórica, no sentido de que não serve à "justiça" da decisão, mas sim à manipulação do próximo com o objetivo de estabelecer, de efetivar os pontos de vista daquele que fala. Perfeitamente; mas a retórica analítica, trazendo os conceitos de retórica material e seu próprio conceito de analítica, pretende outra abordagem, combatendo essa redução metonímica da retórica a apenas uma de suas acepções, a estratégica.

Assume-se aqui que a postura retórica pode dar outra contribuição além de seu nível estratégico e ornamental, ou seja, além de sua ajuda para o sucesso da comunicação. A atitude metódica da retórica pode propiciar mais conhecimento das relações humanas, eventualmente legitimar suas regras, testando seu acordo com as regras do jogo, por exemplo (a lei e outras fontes de normas jurídicas, no caso do direito), além de fornecer apoio à aceitação de decisões.

Para Charles William Morris, a retórica seria uma antepassada da semiótica, uma precursora mais simples. Para Ottmar Ballweg, ao contrário, a semiótica está 
contida na retórica, assim como teorias desconstrutivistas e sistêmicas, dentre outras. Ballweg, que toma por base a semiótica de Morris, objetiva adicionar a dimensão fronética (de fronesis, prudentia) à semiótica de Morris. Essas duas, somadas à dimensão tradicional holotática (de holismo), de que Morris tampouco se ocupou, completam a retórica analítica de Ballweg, cada uma das três com três subdimensões respectivas.

Esquema 2: retórica analítica de Ballweg

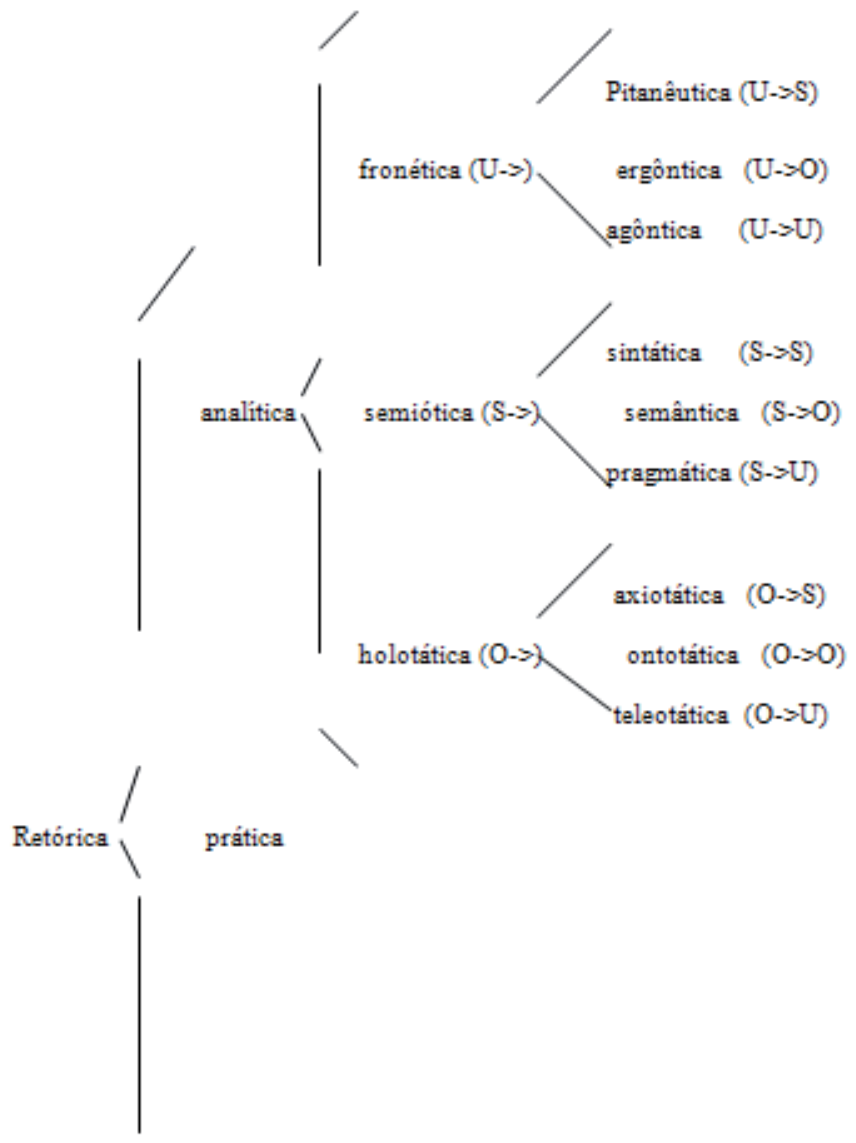

material

A análise retórica holotática visa pôr a descoberto, desconstruir os sistemas lingüísticos holísticos, das ontologias tradicionais, mostrando que também são retóricos 
os "objetos" e "valores" alegadamente extralingüísticos, a "natureza", o "conceito", a "síntese". Na perspectiva holotática da retórica analítica, tal como entendida aqui, os "objetos" são relatos (temporariamente) vencedores. É assim que existem buracos negros no universo e que pode ser calculada a velocidade da luz, ao mesmo tempo em que não existem seres humanos com mil anos de idade. Dependendo do contexto, claro.

Para esclarecer a perspectiva holotática, o termo "holismo" tem origem no adjetivo grego holikós, que significa "universal". Seu emprego moderno parece ter sido inspiração de J. C. Smuts, em 1926. Holística pode ser definida como a tendência, supostamente presente em todo o universo, de que as unidades se agrupem em novas unidades organizadas, progressivamente mais amplas, na direção de uma totalidade harmônica, coordenadas por um princípio ontológico unificador. As três subdivisões da holotática inspiram-se na tripartição semiótica, segundo essa objetivação retórica totalizadora se dê em torno do signo, do próprio objeto ou do sujeito.

A análise retórica semiótica proposta por Ballweg limita-se a incluir as contribuições de Morris, conforme já referido. A semiótica é vista aqui como o mais importante produto da "virada lingüística" do início do século XX, quando a linguagem e seus signos passam a ser reconhecidos como o terceiro elemento irredutível do conhecimento, ao lado das tendências empiristas (Heráclito a Locke) e racionalistas (Parmênides a Descartes) também já referidas.

A análise retórica fronética ou prudencial tenta ir adiante, na medida em que não mais enfatiza o signo, como a semiótica, mas sim os próprios participantes que se utilizam da comunicação, os utentes. Ela constitui a atitude retórica propriamente dita, é a atitude tomada pelo retórico, pois lhe dá uma perspectiva além da material, na qual todos estão imersos, e da prática, que é dominada pelo técnico, pelo especialista. Ou seja: na dimensão prática impera o especialista no tipo de discurso em questão e não o retórico, o teórico geral do discurso.

Partindo da ênfase sobre os utentes (análise prudencial ou fronética) e combinando os três elementos de Morris - utente, objeto e signo -, Ballweg sugere as subdimensões agôntica, ergôntica e pitanêutica, que interessam mais de perto aqui.

Para Ballweg, agôntica (U->U) é a dimensão da fronética que observa como os utentes se interrelacionam, constituindo padrões e maneiras de agir, vale dizer, "semânticas sociais", como as formas de conduta do cortesão, do homme de lettres, do Gentleman, do Caballero etc. ${ }^{31}$

${ }^{31}$ BALLWEG, Ottmar. Entwurf einer analytischen Rhetorik. In: SCHANZE Helmut e KOPPERSCHMIDT, Joseph (Hrsg.). Rhetorik und Philosophie. München: Wilhelm Fink, 1989, p. $39-40$.

Revista Seqüência, no 56, p. 55-82, jun. 2008. 
A analítica agôntica deixa os próprios sinais da comunicação em segundo plano e se concentra na conduta dos utentes. Suas temáticas, exemplifica Ballweg quanto ao direito, giram em torno da definição da figura do sujeito de direito, se uma relação jurídica só se dá entre sujeitos, o que significam credor, devedor, obrigado, inadimplente. Nos sujeitos da política, o que enseja a diferenciação amigo/inimigo? O importante é determinar se as relações entre os sujeitos, abstraindo o quanto possível os sinais pelos quais se expressam, são protagonísticas, sinagonísticas ou antagonísticas, outra forma de mencionar que essas relações vão da cooperação ao conflito.

Para procurar entender melhor a classificação, note-se que a expressão "agôntica" é inspirada em "agonística" (agônistikç). O adjetivo agônistikós remete originalmente ao sentido de "apto a lutar", tendo depois se estendido aos debates e à competitividade que caracterizam a vida pública, assim como à retórica que os acompanha. Como em toda concorrência, a agonística é orientada para a vitória sobre o adversário. A erística é uma das formas estratégicas de expressão nessa luta ${ }^{32}$.

A retórica analítica ergôntica se dá entre intérprete e significado, utente e objeto (U->O), diz Ballweg, e ocupa-se das definições jurídicas, políticas, econômicas etc. que regulam a propriedade, a posse e demais relações com os bens, as "coisas" a que dão valor os seres humanos. Essas relações ergônticas vão influir sobre as relações agônticas entre os sujeitos, pois os bens de toda espécie catalisam intenções e interesses. O dinheiro é a linguagem de controle mais importante nas relações ergônticas, mas essas não se reduzem aos bens econômicos (Ballweg menciona os bens culturais como exemplo).

O termo ergôntica parece ser retirado do grego érgon (Ýñãüí, Ýñãù), que tem basicamente três significados: 1 . ato, manuseio, fato; 2 . trabalho, execução de tarefa, empresa, negócio; 3. o resultado, o objeto produzido por esse trabalho. Em sentido mais figurado pode expressar efetividade.

A terceira subdivisão da fronética Ballweg chamava, a princípio, agorética (Agoretik), a partir da expressão ágora, o local, a praça em que se faziam as assembléias dos cidadãos. Preferiu depois a denominação pitanêutica (U->S), que parece ter sido inspirada no adjetivo pithanós (ðéèáíóò). Em seu sentido ativo, esse adjetivo pode ser aplicado a pessoas e coisas, significando pessoa simpática, que desperta confiança, e coisa provável, confiável; em sentido passivo significa a pessoa fácil de convencer, até obediente.

\footnotetext{
${ }^{32}$ UEDING, Gert (Hrsg.). Historisches Wörterbuch der Rhetorik, Band 2. Darmstadt: Wissenschaftliche Buchgesellschaft, 1994, p. 261.
} 
Ballweg escolhe essa denominação para indicar a dimensão entre os utentes e os sinais de linguagem. Ele insiste que a escolha que o sujeito utente faz dos sinais de linguagem, que constitui a pitanêutica, só faz sentido ao lado das outras duas subdimensões. Observa que essas escolhas também podem ser institucionalizadas, como em diversos contextos no direito dogmático, em que o vocabulário não está ao alvedrio do utente, mas sim previamente vinculado a ônus de fundamentação, pressupostos processuais, ônus de prova, regras contratuais etc. A analítica pitanêutica procura explicar como surge o poder da definição, pelo qual os sistemas lingüísticos são construídos e destruídos.

\section{Desenvolvimentos futuros para uma retórica metódica desestruturante}

Um ponto difícil para estabelecer um diálogo com a retórica analítica de Ballweg está no caráter fragmentário de seus escritos, nos quais as sugestões e insights não são desenvolvidos e dão margem a prolongamentos controversos, conforme se buscou apontar na breve exposição acima. Mesmo assim, como o objetivo aqui não é expor sua doutrina, o diálogo parece ainda mais fecundo.

Por isso procurou-se tornar mais clara a diferenciação entre pitanêutica (utente - signo) e a dimensão pragmática da semiótica (signo - utente), colocando o ponto de partida para uma discussão sobre as separações conceituais entre retórica e pragmatismo, que terá que ser deixada para outra oportunidade.

Ao definir a dimensão agôntica, Ballweg tampouco explica com nitidez como se podem perceber relações entre utentes sem atentar para os signos ou, mesmo, como se pode separar "relação" de "signo", como se houvesse a possibilidade de intersubjetividade sem signos. Nessa direção, este artigo tenta esclarecer a concepção de retórica como condição humana de existência, como a própria matéria da humanidade, pois aí está a base para compreender os três níveis da retórica.

Uma objeção mais geral é que uma retórica metódica precisa dispensar o hábito ontologista de partir da dicotomia sujeito - objeto. Ora, como recusar a categoria sujeito - objeto tomando por base a semiótica de Morris, que incorpora essa distinção? Uma resposta possível, e aqui escolhida, é que a retórica apenas registra e analisa que essa "categoria" sujeito - objeto constitui uma forma da comunicação humana, sem assumir seu caráter necessário. Quer dizer, a comunicação humana criou a oposição e a utiliza, obrigando o retórico a considerá-la.

A retórica precisa considerar que jamais trata de sujeito, no singular, mas sempre de utentes de signos, para que a perspectiva relacional, intersubjetiva, afas- 
te tanto os riscos do objetivismo empirista, reificador, quanto aqueles do subjetivismo cartesiano, ambos ontológicos. A retórica se dá entre sujeitos, não há, a rigor, objetos (coisas), como dito; e objetos são acordos lingüísticos que os sujeitos estabelecem em conjunto, sempre condicionais, temporários e auto-referentes, conforme também enfatizado.

Ressalte-se que, na perspectiva metódica proposta aqui, a retórica não se limita ao consenso, como querem retóricos contemporâneos, os quais permanecem atrelados à função metodológica da retórica ${ }^{33}$. A retórica metódica também se afasta tanto do procedimentalismo de Habermas e outros, quanto da hermenêutica filosófica de Gadamer e seus discípulos, pois a pré-compreensão implica o conceito de convicção de verdade, condicionada ao mundo da vida, o que não se coaduna com os pressupostos analíticos.

Mesmo na dimensão metodológica, note-se que a busca do consenso nem sempre é o caso e que a retórica também se constitui na ação estratégica, em ameaças e outras formas de controle de dissenso. Retórica metódica tampouco se confunde com a hermenêutica tradicional, pois esta é muito mais textual, tendo surgido da exegese de textos bíblicos e talmúdicos. A retórica é grega, envolve ethos, pathos, logos, oralidade, gestualidade e, também, textos.

No mesmo sentido de diferenciar-se, a retórica procura manter ao largo conceitos como os de eficácia ou positivação "simbólica" do direito ou de outras linguagens, pois toda eficácia, toda manipulação da "realidade", toda positivação é simbólica. Não há evidências de uma "eficácia real", uma "verdadeira eficácia", para ser comparada à eficácia simbólica, apenas inúmeras e diferentes possibilidades, todas simbólicas.

Resumindo os aspectos construtivos sugeridos aqui, além do objetivo geral de situar o que significa a postura mais abrangente da retórica contemporânea, a tese é que utilizar os conceitos de método, metodologia e metódica vai tornar mais precisa a classificação da atitude retórica em material, prática e analítica. Essa depuração conceitual enfatiza a retórica analítica como a atitude filosófica mais adequada, tanto para conhecer o mundo (gnoseologia) como para avaliá-lo (ética) e agir.

\footnotetext{
${ }^{33}$ Afirma que a teleologia da retórica é obtenção de consenso GAST, Wolfgang. Die sechs Elemente der juristischen Rhetorik: Das Modell rhetorischer Kommunikation bei der Rechtsanwendung, in: SOUDRY, Rouven (Hrsg.). Rhetorik - Eine interdisziplinäre Einführung in die rhetorische Praxis. Heidelberg: C. F. Muller Verlag, 2006, p. 32.
} 


\section{Referências}

ADEODATO, João Maurício. Ética e retórica - para uma teoria da dogmática jurídica, 3. ed. rev. e ampl. São Paulo: Saraiva, 2007.

. Filosofia do direito - uma crítica à verdade na ética e na ciência, 3 . ed. rev. e ampl. São Paulo: Saraiva, 2005.

ARISTOTLE. Rhetoric. Trad. W. Rhys Roberts. Col. Great Books of the Western World. Chicago: Encyclopaedia Britannica, 1990, v. 8.

APEL, Karl-Otto. Wittgenstein und Heidegger: Kritische Wiederholung und Ergänzung eines Vergleichs, in: McGUINESS, Brian (Hrsg.). Der Löwe spricht... und wir können ihn nicht verstehen. Ein Symposion an der Universität Frankfurt anläßlich des hundertsten Geburtstags von Ludwig Wiittgenstein. Frankfurt a.M.: Suhrkamp, 1991.

BAILLY, Anatole. Dictionnaire Grec Français (rédigé avec le concours de E. Egger). Paris: Hachette, 2000 (27e. ed.).

BALLWEG, Ottmar. Entwurf einer analytischen Rhetorik. In: SCHANZE Helmut e KOPPERSCHMIDT, Joseph (Hrsg.). Rhetorik und Philosophie. München: Wilhelm Fink, 1989.

BALLWEG, Ottmar. Phronetik, Semiotik und Rhetorik, in: BALLWEG, Ottmar; SEIBERT, Thomas-Michael (Hrsg.). Rhetorische Rechtstheorie. FreiburgMünchen: Alber, 1982.

CANECA, Frei Joaquim do Amor Divino. Tratado de eloqüência. In: Obras políticas e literárias (colecionadas pelo Comendador Antonio Joaquim de Mello). Recife: Typographia Mercantil, 1875 (ed. fac simile, 1972, p. 63-155). CHAUÍ, Marilena. Convite à filosofia. São Paulo: Ática, 2001. COHEN, Hermann. Logik der reinen Erkenntnis, Helmut Holzhey (Hrsg.). Werke Bd. 6, 1. Teil (System der Philosophie). Hildesheim/New York: Georg Olms Verlag, 1977.

GAST, Wolfgang. Die sechs Elemente der juristischen Rhetorik: Das Modell rhetorischer Kommunikation bei der Rechtsanwendung, in: SOUDRY, Rouven (Hrsg.). Rhetorik - Eine interdisziplinäre Einführung in die rhetorische Praxis. Heidelberg: C. F. Muller Verlag, 2006.

GIL CREMADES, Juan José e RUS RUFINO, Salvador. Estudio preliminar, in THOMASIUS, Christian. Historia algo más extensa del derecho natural. Madrid: Tecnos, 1998.

GUTHRIE, W. K. C. The sophists. Cambridge: Cambridge University Press, 1991. 
KIRSTE, Stephan. Einleitung, in: KIRSTE, Stephan; WAECHTER, Kay; WALTHER, Manfred (Hrsg.). Die Sophistik - Entstehung, Gestalt und Folgeprobleme des Gegensatzes von Naturrecht und positivem Recht. Stuttgart: Steiner, 2002.

LIDDEL, Henry George e SCOTT, Robert (comp.). A Greek-English Lexicon. Oxford: Clarendon Press, 1996.

NERI, Demétrio. Filosofia moral - manual introdutivo. Trad. Orlando Soares Moreira. São Paulo: Loyola, 2004.

MONTINARI, Mazzino (Hrsg.): Friedrich Nietzsche Kritische Studienausgabe - in fünfzehn Bände, vol. 5. Berlin: Walter de Gruyter, p. 245424 (II, 13, p. 317).

NIETZSCHE, Friedrich. Zur Genealogie der Moral - Eine Streitschrift. in COLLI, Giorgio -

PELLEGRIN, Pierre. Le Vocabulaire d'Aristote. Paris: Ellipses, 2001.

Revista Brasileira de Filosofia, n. 163, fasc. 39. São Paulo: Instituto Brasileiro de Filosofia, 1991, p. 175-184.

SCHOPENHAUER, Arthur. Eristische Dialektik, in: SCHOPENHAUER, Arthur. Sämtliche Werke, 6. Band. DEUSSEN, Paul (Hrsg.). München, 1923. SKINNER, Quentin. Reason and rhetoric in the philosophy of Hobbes. Cambridge: Cambridge University Press, 1996.

UEDING, Gert (Hrsg.). Historisches Wörterbuch der Rhetorik, Band 2. Darmstadt: Wissenschaftliche Buchgesellschaft, 1994.

UEDING, Gert. Was ist Rhetorik?, in: SOUDRY, Rouven (Hrsg.). Rhetorik Eine interdisziplinäre Einführung in die rhetorische Praxis. Heidelberg: C. F. Muller Verlag, 2006.

VIEHWEG, Theodor. Topik und Jurisprudenz - Ein Beitrag zur rechtswissenschaftlichen Grundlagenforschung. München: C. H. Beck, 1974 (4. Aufl.). SCHLIEFFEN, Katharina von. Rhetorische Analyse des Rechts: Risiken, Gewinn und neue Einsichten, in: SOUDRY, Rouven (Hrsg.). Rhetorik - Eine interdisziplinäre Einführung in die rhetorische Praxis. Heidelberg: C. F. Muller Verlag, 2006. 